med at være en uforløst læsning af et skrift, der ikke kan bære Korsgaards ambitioner om originalitet.

Afslutningsvis kan man overveje, om ikke også titlen Grundtvig rundt er misvisende. Den lægger op til en egentlig gennemgang også af Grundtvigs teologi, af hans digtning, inkl. salmerne, af oversættelserne måske og af hans mangeårige arbejde med historie og myter - som man ganske enkelt ikke får. Vi guides rundt i nogle ganske vist væsentlige temaer, men flere af disse temaer er ofte for ujævnt eller af og til direkte misvisende fremstillet til at være gode og anbefalelsesværdige.

Spørger man nu om den gode Grundtvigindføring, falder svaret af sig selv: Anders Holms. Men det er skuffende, at der ikke er to muligheder. Nok kan der henvises til adskillige kapitler i Korsgaards bog, som er gode, men det er ikke det samme som en god bog.

\title{
Nyaars-Morgen som symfonisk digt
}

\author{
Jesper Høgenhaven
}

Jørgen I. Jensen, Denne ene sommer. Grundtvigs Nyaars-Morgen som symfonisk digtning, Vartov Forlag i samarbejde med Grundtvig Centeret, 174 sider, 198 kr.

Det er en personlig bog, Jørgen I. Jensen har skrevet om Grundtvigs storslåede digt fra 1824 - personlig i den bedste forstand af ordet: Forfatteren tager generøst sin læser med ind i sin egen læseroplevelse af Nyaars-Morgen; og man er ikke et øjeblik i tvivl om Jensens dybe betagelse af Grundtvigs værk. Bogen kan tjene som en indføring i Nyaars-Morgen for den, der gerne vil stifte bekendtskab med digtet, men er tilbøjelig til at lade sig skræmme af dets ry for uforståelighed. Samtidig rummer Jensens bog 
også masser af inspiration for den, der kender Nyaars-Morgen i forvejen. Jensen læser Grundtvig med et engagement og en utilsløret fascination, der smitter, og med et skarpt analytisk blik for enkeltheder og litterære, historiske og teologiske sammenhænge. Bogens stil har noget essayistisk let og flydende over sig, og der associeres til fortidige og nutidige fænomener med stor frihed og glæde. Bag ved letheden ligger der imidlertid en dyb og omfattende lærdom og en fortrolighed med Grundtvig, hans tid og europæisk åndshistorie i det hele taget.

Bogens hovedsynspunkt er udtrykt i undertitlen: Jensen vil læse NyaarsMorgen som et symfonisk digt, en genrebetegnelse hentet fra den romantiske musik. Selve betegnelsen "symfonisk digt" går tilbage til Franz Liszt; men den programmusikalske ide, hvor musikværker får litterære titler og henter inspiration fra digtekunsten, begynder tidligere i 1800-tallet. Hvor det symfoniske digt som musikalsk genre lader sig inspirere af litteraturens verden, forsøger Jensen at gå den modsatte vej med en tolkning af Grundtvigs digt, der henter sin inspiration i musikken. Et afsæt for denne tolkning finder Jensen i den rolle, det auditive spiller i Nyaars-Morgen. Jensen inddrager i den forbindelse værkets tilblivelseshistorie og peger på Grundtvigs dokumenterede slid med via flere forsøg at finde frem til den enestående rytme i digtet: Den sidste - urimede - linje i hver strofe danner med sine otte stavelser en markeret afslutning. Den kommer på én gang til at stå som en art selvstændig kommentar til den strofe, der går forud, og som en videreføring til det næste, der kommer.

Men ud over rytmens og versemålets betydning forekommer der i Nyaars-Morgen et stort antal vigtige lydlige billeder. Digtet indeholder en spænding eller et spil mellem det auditive og det visuelle. Jensen peger på mundtligheden eller det lydlige som den form, digtet er skabt med. Når man bliver opmærksom på vigtigheden af det auditive, kan det lette på noget af den tyngde, som den indgroede ide om digtets uforståelighed har bebyrdet fortolkningen af Nyaars-Morgen med. Jensen citerer Grundtvigs oneliner (Jensens udtryk): "Lyd er Legem, Skrift er Skygge" (fra "Jesus! Hvor er Du dog henne?” GSVI, 35, str. 10). Når teksten først og fremmest skal høres, får ordenes og strofernes klang, lydmaleriet i digtet eller den musikalske dimension en afgørende betydning ud over spørgsmålet om, hvad hver enkelt sætning betyder.

Jensen tolker Grundtvigs digt ved hjælp af den klassiske musiks sonateform med de tre hovedelementer eksposition, modulationsdel (gennemfø- 
ring) og reprise. Det er en tolkningsnøgle, som Jensen også tidligere har været inde på og har argumenteret for (Det forste ord. Teologiske rapporter fra en musik- og kulturby. Efter et århundredskifte, Aros 2013). For nylig har Kristoffer Garne i sin prisopgave (Romantik og kristendom belyst gennem Grundtvigs andet møde med Steffens, Publikationer fra Det Teologiske Fakultet 63, 2016) også tydelig vist det frugtbare i denne opfattelse af Nyaars-Morgen - selvfølgelig med behørig henvisning til Jensen. Ekspositionen i Nyaars-Morgen er de tre første sange, hvor de to hovedtemaer gennem hele værket introduceres og gennemspilles første gang: på den ene side Grundtvigs ungdommelige fascination af den nordiske hedenske mytologi og sagnverden og på den anden side det kristne gennembrud. Modulationsdelen udgøres af fjerde til syvende sang, hvor digtets jeg bliver til romantikkens ensomme vandrerfigur. Denne lange midterste del af digtet ligger hen i en belysning præget af tåge, tusmørke og nat (her optræder spøgelser og gengangere) og er i det hele taget præget af store følelsesmæssige udsving. Kampen bølger frem og tilbage; og samtidig lades der op til reprisen: De afsluttende strofer af syvende sang indeholder værkets største og mest gådefulde apokalyptiske udladning: Her beskrives en opløsning af jegets gåde som en forvandling af vand til vin - men forvandlingen finder sted på baggrund af og med afsæt $\mathrm{i}$ en omvendt forvandling, hvor vinen er blevet til vand for at opløses og optage alt i sig. Det er et syn, der skildres her til sidst i modulationsdelen (svarende til, at symfonisatsens modulationsdel netop slutter med en voldsom udladning før reprisen), hvor fiskene skal synge til sidst, og de nordiske svaner flyve ind i paradiset. Reprisen bliver så ottende til tiende sang. Ottende sang indledes med ordene: "Det Sidste jeg mindes", og viser dermed tilbage til begyndelsen af anden og tredje sang (hvor de samme ord “... jeg mindes" også forekommer). Nu er Grundtvig kommet ud på den anden side af midterdelens voldsomme og uafklarede kampsituation. Han er tilbage i en "almindelig" Danmarkshistorie og bibelhistorie, spøgelserne og gengangerne fra fjerde til syvende sang er nu forsvundet.

Den tolkning af strukturen i Nyaars-Morgen, som Jensen lægger frem, bidrager ikke kun til at skabe oversigt og sammenhæng i digtets gentagelser og henvisninger til og genoptagelser af temaer, der bliver brugt tidligere. Jensen peger også på en dybere sammenhæng imellem sonateformen i musikken og den opfattelse af tiden, som er indlejret i den kristne tradition specielt siden Augustin. På den ene side er tiden i den klassiske kristne 
forståelse et lineært forløb, hvor Kristi inkarnation, død og opstandelse er enestående, uigentagelige begivenheder, som alt efterfølgende er relateret til og i en vis forstand må udspringe af. Her står kristendommens syn på tiden i modsætning til den hedenske forestilling om altings genkomst, hvor tiden bliver cirkulær. På den anden side rummer den kristne tradition også den tanke om en gensidig forbindelse mellem fortid, nutid og fremtid, som kommer til udtryk i den typologiske bibelfortolkning. Her peger den gammeltestamentlige figur frem mod den nytestamentlige figur, der er beslægtet med den. Men begge figurer peger samtidig mod noget fremtidigt, noget endnu ikke indtruffet, som er den endelige opfyldelse. Tiden bliver dermed på én gang en bue (fra den gammeltestamentlige til den nytestamentlige figur) og en linje, der fører videre mod opfyldelsen, som kommer udefra som noget nyt, ikke som en organisk fortsættelse af det foregående.

Denne tidsopfattelse finder Jensen indlejret på en særlig markant måde i Nyaars-Morgen. Det er også denne fornemmelse for tiden, der kommer til udtryk i sonateformens kombination af gentagelse og videreføring. Jensen henviser til Hadding-sagnets centrale betydning i Grundtvigs digt og påviser, hvordan Grundtvig fra et tidligt tidspunkt længe før Nyaars-Morgen havde været optaget af dette førnordiske keltiske sangstof. I NyaarsMorgen bliver Haddings nedfart til underverdenen med den gådefulde kvindefigur som fører et af digtets bærende billeder. Jensen peger også på den betydning, Sigrid-skikkelsen har i digtet: I den forunderlige scene i femte sang, hvor digtets jeg er fulgt med kvindeskikkelsen ned gennem fortiden til ismuren, river kvinden hovedet af en hane og kaster det over på den anden side af muren. Nu begynder ismuren at smelte; og i det samme løfter Sigrid ("den Sol-Datter skjøn”) sit øje, og hendes blik bliver ét med den varmende sol. Jensen argumenterer for Sigrids forbindelse med digtets symbolverden - hun er både solen og tillige (i ottende sang) selveste kærlighedsgudinden Freia.

Bogens titel henviser konkret til sommeren 1824 som et skelsættende tidspunkt ikke alene i Grundtvigs liv og digterbane, men også som et kulturhistorisk afgørende skel. Der er et skifte på vej fra den romantik, som har fyldt scenen siden århundredskiftet, og som Oehlenschläger og Ingemann er repræsentanter for. Det nye, der er ved at vise sig, er en mere realistisk, jordnær romantik som hos Blicher og Poul Møller. Den intense oplevelse af fortiden og historien som noget virkeligt og på godt og ondt 
nærværende, som den tidlige romantiske erfaring står for, er ved at fortone sig. Jensen taler om en "seismografisk sikkerhed i forhold til tidsånden og dens skiften" hos Grundtvig. Han må have vidst eller i hvert fald anet, at det nu var sidste udkald, hvis hele den erfaring af det forbigangnes og det nuværendes enhed, som han selv var opfyldt af, skulle have et blivende udtryk. I det lys får det ekstra god mening, at der er et så markant element af tilbageskuende selvbiografisk orientering i Nyaars-Morgen, og at Grundtvig her foretager det dybeste dyk ned i den hedenske mytologiske verden og i den nordiske fortid - han er nødt til at have det hele med sig ind i nutiden og fremtiden, og det er nu eller aldrig.

Bogen er rig på fine iagttagelser og vidner om et sikkert og overbevisende overblik over digtets - og Grundtvigs - billedverden. Det siger sig selv, at der på blot 174 små sider ikke bliver plads til en detaljeret gennemgang eller tolkning af særligt mange af Nyaars-Morgens strofer. Og det giver næsten sig selv, at der er fortolkninger, som kalder på diskussion og uenighed. Der er masser af emner, man kunne ønske sig at læse meget mere om hos Jensen. Det gælder betydningen af det norske landskab over for det danske, hvor der peges på en bevægelse gennem Nyaars-Morgen fra det første til det andet. Og det gælder den måde, hvorpå store dele af Grundtvigs senere virksomhed synes at være aftegnet $\mathrm{i}$ stroferne 301-306 i tiende sang. Jørgen I. Jensen har ikke skrevet en fortolkning til hele Grundtvigs digt, sang for sang eller strofe for strofe. Bogen er tænkt med et andet sigte, som den opfylder til fulde: Den er en invitation til at fordybe sig i den rigdom, som ligger gemt i Nyaars-Morgen. 